Koen Abts, Emmanuel Dalle Mulle, Stijn van Kessel, Michel Elie

\title{
The Welfare Agenda of the Populist Radical Right in Western Europe: Between Welfare Chauvinism, Producerism and Populism
}

This is the pre-peer reviewed version of the following article: Abts, K., Dalle Mulle, E., van Kessel, S., \& Michel, E. (n.d.). The Welfare Agenda of the Populist Radical Right in Western Europe: Combining Welfare Chauvinism, Producerism and Populism. Swiss Political Science Review, Advanced online. https://doi.org/10.1111/spsr.12428. This article may be used for non-commercial purposes in accordance with Wiley Terms and Conditions for Use of SelfArchived Versions.

\begin{abstract}
Recent contributions argue that populist radical right parties (PRRPs) converge around a 'welfare chauvinist' position, and that their welfare policies are inspired by their nativism, authoritarianism and populism. Yet a more precise appraisal of PRRPs' welfare positions, as well as their underlying logic, is still lacking. This paper proposes an analytical framework that considers the multidimensionality of welfare state positions as well as 'deservingness criteria' underlying ideas about welfare entitlement. Our study investigates a sample of four European PRRPs. It concludes that PRRPs share a welfare agenda based on three interrelated frames. They advocate social closure based on the deservingness criterion of identity (welfare chauvinism); but additionally propose a selective distribution of welfare based on criteria of control, attitude, and reciprocity (welfare producerism), and criticise existing welfare arrangements through the prism of a vertical antagonism between the people and the establishment (welfare populism).
\end{abstract}

Keywords: welfare state, populist radical right, welfare chauvinism, welfare producerism, welfare populism. 
In recent years, extensive attention has been given to the rise populist radical right parties (PRRPs) (Mudde 2007). While the xenophobic, authoritarian and populist profile of the populist radical right (PRR) has been well-documented, scholars have only recently analysed systematically the positions of PRRPs with regard to socio-economic issues. In the $1990 \mathrm{~s}$, the rise of radical right-wing parties in Western Europe has been associated with a backlash against the excessive role of the state. Hans-Georg Betz (1994) suggested that radical right parties present a classical liberal position on the economy, while Herbert Kitschelt and Anthony McGann (1995: 42) similarly argued that successful radical right parties stuck to a 'winning formula' consisting of an authoritarian and nationalistic appeal coupled with a neoliberal pro-market position on socio-economic issues. The winning formula thesis has, however, attracted considerable criticism, and has been largely revised (McGann and Kitschelt 2005). Notably, Kitschelt (2007) argued that his theory was time-specific (19801990s), and that PRRPs' positions on the economy were ultimately secondary to their cultural agenda. These clarifications notwithstanding, the precise position of the PRR on socioeconomic issues still remains contentious and under-researched (Afonso 2015). While some accounts infer that PRRPs have shifted to a more centrist position (De Lange 2007), other scholars argue that they are neither right nor left because they subscribe to neoliberal, nationalist as well as statist views (Hainsworth 2000: 28), or combine economic populism with welfare chauvinism (Kriesi et al. 2012). Yet others suggest that PRRPs devote little attention to socio-economic issues, or even consciously aim to 'blur' their economic policy positions (Rovny 2013). Accordingly, issues such as economic redistribution and market regulation would be secondary to the programmes of PRRPs, as well as to the concerns of their voters (Mudde 2007; Ivarsflaten 2008; Oesch 2008). 
However, an increasing body of research shows that West European PRRPs place considerable emphasis on socio-economic issues and are converging around a 'welfare chauvinist' position (see e.g. Andersen and Bjørklund 1990; De Koster et al. 2013; Ivaldi 2015; Lefkofridi and Michel 2017). Welfare chauvinism essentially entails support for economic redistribution and the preservation of welfare state entitlements, whereby the nonnatives are excluded from welfare provisions, or only have limited access. While it is acknowledged rather widely that PRRPs typically advocate a form of 'exclusive solidarity' (Lefkofridi and Michel 2017), their welfare agenda can still be conceptualised more accurately. For one, the term 'welfare chauvinism' remains ambiguous, as it can denote a prioritisation of the native population ('welfare favouritism'); an all-out exclusion of nonnationals from welfare provisions ('direct welfare chauvinism'); or policies that negatively affect migrants ('indirect welfare chauvinism') (Careja et al. 2016). Besides, PRRPs' positions on different dimensions of the welfare state also remain unclear. Notwithstanding a few exceptions, comparative studies on the radical right often fail to discriminate between various welfare policy areas (e.g. pension, healthcare and unemployment benefits) or to take into account the multi-dimensionality of the positions toward the welfare state in terms of its scope, design and implementation. In our contribution, we address these gaps by proposing an analytical framework that considers the multidimensionality of welfare arrangements and deservingness criteria, which are drawn from the relevant sociological literature (e.g. Van Oorschot 2006; Roosma et al. 2013).

For reasons of scope, and in order to conduct an in-depth analysis, we limit our framework to redistributive social policies, excluding regulative economic policies. We apply this framework to four PRRPs through a longitudinal and cross-country comparison, inferring the 
specific position of these parties on different aspects and policy areas of the welfare state. In other words, this contribution focuses on the contents rather than on the determinants or consequences of PRRPs' welfare agendas, providing a more precise understanding of PRRPs' positions regarding the welfare state and welfare deservingness. We find that irrespective of some noteworthy variation - PRRPs share a typical welfare agenda that is based on three frames: (1) welfare chauvinism: advocating social closure based on the deservingness criterion of identity; (2) welfare producerism: proposing a selective distribution of welfare based on criteria of control, attitude, and reciprocity; and (3) welfare populism: criticising existing welfare arrangements through the prism of a vertical antagonism between the people and the establishment.

2.

\section{Current Research on the Welfare State and PRRPs}

Most studies of the PRR focus predominantly on its welfare chauvinist agenda, considering calls to exclude immigrants from welfare provision primarily as a facet of its nativist ideology. This interpretation is problematic as it is misguided to interpret the welfare agenda of the PRR in either economic or cultural terms (Derks 2006). The desired exclusion of immigrants from entitlements may be largely based on the criterion of identity (e.g. nationality and ethnicity), but the arguments as to why immigrants should be excluded often refer to collective interests and reciprocity. Indeed, political struggles about the welfare state ‘are always both distributional conflicts and value conflicts' (Häusermann 2010).

Other studies argue that PRRPs are departing from their strictly cultural agenda and campaign increasingly on welfare issues to compete for economically left-leaning voters (Lefkofridi and Michel 2017). In fact, the more PRRPs engage with policy positions on the 
welfare state, the more their preferences are considered left-wing (Afonso and Rennwald 2018). These contributions assume that PRRPs adapt their political preferences to an increasingly working-class electoral constituency. Another strand of research on the PRR's welfare state agenda focuses on its political and policy consequences. PRRPs participating in governing coalitions, for instance, were found to favour the restructuration of the welfare state and welfare retrenchment (Afonso 2015; Keskinen et al. 2016).

A more recent trend in the literature, initiated by Ennser-Jedenastik $(2016,2018)$, investigates the welfare agenda of PRRPs in a more detailed fashion (see also Otjes et al. 2018). EnnserJedenastik's group-based approach proposes to go beyond the classical left-right division and argues that the PRR's social policy positions stem from its core ideological traits of nativism, authoritarianism and populism. Combined with the literature on principles of social justice, this framework allows for predicting what kind of social policy instruments and areas the PRR prioritises. This approach takes a first step towards linking the PRR and welfare state literature (see also Fenger 2018).

Yet these studies still face two important shortcomings. First, they omit the multidimensionality of the welfare state, which is not limited to deservingness and the analysis of different social policy areas, but also involves questions concerning responsibility for welfare, the range and scope of welfare arrangements, and the effectiveness, efficiency and (un)intended consequences of the redistribution process. Second, existing studies do not take into account the literature on welfare deservingness related to the normative question of 'who should get what, when, and why' (Van Oorschot 2006), which would facilitate a more accurate assessment of the PRR's welfare agenda. 
In a broad sense, the welfare state can be defined as a set of institutions 'predominantly preoccupied with the production and distribution of social well-being' (Esping-Andersen 1990: 1). More precisely, welfare states are social arrangements in which individuals accept a certain degree of redistribution in order to rebalance inequalities created by market dynamics (Mau 2003: 1-2). In this way, welfare states act as powerful institutional stabilisers of social relations and redistributors of life chances, enabling a more equal distribution of opportunities and a socialisation of risk (Ferrera 2005: 14). Created within the framework of nation-states (Bommes 2012: 38-39; Brubaker 1989: 155-156), welfare states have acted as powerful nation-building tools, providing the legitimate community of recipients with unprecedented levels of security while simultaneously strengthening the legitimacy of the state (Esping-Andersen 2004: 27). This process occurred through a mechanism of social closure whereby internal bonding and inclusion required external bounding and exclusion (Ferrera 2005: 2-4; Freeman 1986: 52-53; Bommes 2012: 39).

The institutionalised solidarity of West-European welfare states thus relied on a double social contract, i.e. the idea of a cohesive community sharing special ties of reciprocity among its members, as well as between these members and the state. From a sociological perspective, the stratification of social ties makes the welfare state a multi-dimensional reality. More specifically, elaborating upon the theoretical framework developed by Roosma et al. (2013), we distinguish between three major dimensions of the welfare state: agency and scope; redistribution design; and implementation and outcome.

First, agency and scope refer to the questions of which institutions should take care of 
redistribution (the state, the market, the family, or private institutions); which types of welfare state instruments should be privileged (social services, social benefits or active labour market policies); and how much the welfare state should redistribute, usually measured as the range and degree of welfare spending.

Second, redistribution design captures the issues of who should get what, and who should pay for it. In other words, it relates to the social contract of mutual support among citizens implicit in welfare arrangements. It is informed by ideas of solidarity, equality and justice, but also of trust and fairness, whereby redistribution, meant as a fair distribution of benefits and burdens, has become a well-entrenched norm (Mau 2003: 88-184). In order to analyse PRRPs' positions on social justice and 'legitimate redistribution', we rely on the literature on welfare deservingness that identifies the criteria determining whether specific categories of welfare recipients enjoy legitimate public support (Feagin 1972; Feather 1974; Cook 1979; Coughlin 1980; De Swaan 1988; Will, 1993; Pettersen 1995). In particular, Van Oorschot $(2000,2006)$ distinguishes five criteria of deservingness (often referred to with the acronym CARIN): (1) control - people who are personally responsible for their state of neediness are considered as less deserving; (2) attitude docility - gratefulness and good morals increase the degree of deservingness; (3) reciprocity - those who have contributed and who have done something in return for support are seen as more deserving; (4) identity - people who belong to 'our' socially defined in-group are more deserving; and (5) need - people are more deserving if they are in greater need of help (see also Van Oorschot et al. 2017).

Third, the implementation and outcome dimension pertains to the questions of how efficiently and effectively welfare arrangements work. It relates to the second implicit social contract underlying welfare arrangements: the existence of a pact of loyalty and service provision 
between the citizens and the state, where the legitimacy of the latter is conditional on the appropriate delivery of welfare services (Bommes 2012: 39). Implementation concerns the cost-effectiveness and quality of service delivery. It pertains to the question of whether welfare ends up with those who genuinely need it, or whether there are situations of abuse/underuse. The 'outcome' facet touches upon the attainment of the welfare state's goals. Do existing arrangements provide more equality and security, or is the current functioning of the welfare state characterised by unintended and unwanted economic and moral consequences?

Starting out from this analytical framework, the three research questions guiding our study are: (1) are PRRPs in favour of welfare state retrenchment, maintenance, or expansion; (2) which 'deservingness criteria' do they prioritize in their discourses about welfare; and (3) who do PRRPs hold responsible for the current (suboptimal) functioning of the welfare state?

\section{[Table 1 about here]}

We analyse PRRPs' welfare discourse in four Western European countries: Belgium, France, Italy, and the Netherlands. Our selected cases include the Belgian Vlaams Blok/Belang (VB); the French Front National (FN); the Italian Lega Nord (LN); and the Dutch Partij voor de Vrijheid (PVV). This sample allows us to analyse different types of welfare regimes: two continental welfare systems (Belgium and France), one Mediterranean (Italy) and a hybrid one (the Netherlands) ${ }^{1}$. Selecting cases from various welfare systems allows us to control for the potential impact of welfare regimes on PRRPs' agendas. In addition, we sought variation in terms of the parties' governing experience, given that incumbency status and party strategy (in terms of seeking policy, office or votes) may influence PRRPs' policies. We thus selected 
cases that have been permanently in opposition (VB and $\mathrm{FN}$ ), one case with governing experience (LN) and one with experience as support partner for a minority coalition (PVV). Our cases also show variation in terms of their age, electoral strength and the type of democracy in which they operate, ranging from majoritarian (France) to consensual (Belgium). All in all, if we find a common welfare agenda between our PRRPs, we can be reasonably certain that this agenda stems from their core ideology, and not from contextual, institutional and strategic conditions.

We perform qualitative content analysis of PRR party documents, dating from the parties' electoral breakthrough onwards. Since not all parties use the same media in outlining and propagating their programmes, the sources we use for each case show a certain degree of diversity. Our data generally include election manifestos, complemented by propaganda documents and policy briefs, published in the years immediately before or after national elections. The full list of sources is available in the supplementary material.

The coding of our documents - available in an Excel spread sheet in the supplementary material - has been structured along the three welfare dimensions as summarised in Table 1. Concerning the 'Agency and Scope' dimension, we have reported all references (in each document) in which parties state their position with regard to the question of "who should take care of welfare and how much?'. More precisely, we have collected information about the parties' stances on their preferred welfare mix, what type of arrangements should be prioritised and how much should be spent (notably, whether the welfare state should be expanded, retrenched or recalibrated). Concerning the 'Deservingness' dimension, we have coded in each document those references in which the parties made clear their position on 'who should get what, and who should pay for it?'. This part of the coding scheme was 
organised around the CARIN criteria seen above - control, attitude, reciprocity, identity and need (Van Oorschot et. Al, 2017) - and we also noted how the parties sought to finance the proposed measures. The last dimension, 'Implementation and Outcomes', examines the parties' statements on the efficiency and effectiveness of welfare arrangements, and the unintended negative consequences of the welfare state. As the documents are listed chronologically, the coding results allow for a comparative evaluation of policy positions not only across cases, but also longitudinally.

The qualitative content analysis aims at identifying the core arguments made by each party along each of the welfare dimensions identified in our framework. Apart from entailing the definition of a clear corpus of sources and of dimensions along which party arguments can be structured and analysed (see above and the supplementary material), this qualitative methodology focuses on the identification of the 'chains of concepts' composing the arguments made by the case-study parties. A quantitative approach would be less appropriate to this end, given that it is not the amount of particular references that makes an ideology, but rather how claims and positions are connected to each other. In this way we want to explore and understand the discourse through which the parties constitute their welfare positions (see section 4). Finally, in section 5, we relate the arguments identified in the preceding sections to each other and to the existing literature on the PRR, and propose a discursive triangle based on three major frames that defines the specific PRR welfare ideology as a particular configuration of interconnected positions. 


\section{Agency and Scope}

Several contributions described the transition of West European PRRP positions from neoliberal in the 1990s, towards 'welfare chauvinist' in later years, involving increasing support for the welfare state (De Koster et al. 2013; Ivaldi 2015; Lefkofridi and Michel 2017). Three out of our four cases (FN, LN, and PVV) have shown a similar transformative trend, despite temporal and case variance. All parties moved from neoliberal positions to ones that allowed for more welfare generosity. In recent years, furthermore, the welfare state has become a more salient topic for them.

We observe this pattern when we take a closer look at the PRRPs' preferred scope of the welfare state. In the 1980 s, the Front National pledged to cut back the 'overreaching and impotent' state, arguing that welfare schemes of socialist governments had instilled a 'right to idleness' (FN 1988c). Yet the party gradually moved to more expansive welfare policies while insisting on the concept of 'national preference' as the core of its welfare programme since the 1980s (FN 1988a). In 2012, Marine Le Pen went so far as proposing to create a new branch of social security focused on old-age and dependency (FN 2012b). Similarly, the Lega showed a quite liberal economic outlook in the early 1990s, calling for the reduction of taxes and public spending, a more efficient and leaner public administration, and the privatisation of a wide range of services (LN 1992, 1994, 1996). Although liberal arguments, notably the reduction of taxes, remain a mainstay of the party's rhetoric (see for instance LN 2008a; Mariani 2013), LN toned down its liberalism in the 2000s (see Mariani 2006; Cota 2008; Iezzi 2013a). Notably, in the context of the economic crisis, LN proposed the expansion of specific welfare programmes regarding housing, family policy, old-age pensions, and 
healthcare (Leoni 2008; Baiocchi 2013a; Ballarin 2013; Iezzi 2013b). Geert Wilders' PVV followed a similar trajectory, albeit over a much shorter span of time. From the beginning in 2005, the party has favoured free-market capitalism and minimal state involvement, while lamenting the fact that many citizens were dependent on government subsidies and benefits (Wilders 2005). Some years later, however, the party repeatedly spoke of the welfare state as a 'source of pride', which had painstakingly been built up, and required protection (PVV 2010a: 21). Despite its continued demand for lower taxes and a leaner state, the PVV thus became evidently less hostile to state intervention in the area of social security.

In comparison with the three other cases, the VB has expressed a more ambiguous welfare agenda, with a less linear evolution. In the 1980s the party objected to state intervention in regulative economic policies, but considered social security to be the full responsibility of the state, and explicitly opposed privatisation (VB 1982). The party combined a neo-liberal rhetoric with protectionist nationalism and community-bounded solidarity, integrated in socalled 'solidarism' (Smout 1989; VB 1981). However, in the early 1990s, VB supported neoliberal policies demanding less state intervention, a reduction of the welfare state and more individual responsibility (VB 1993a, 1993b). Afterwards, when it presented itself as a 'social people's party' in the 2000s (VB 2013), VB's positions became more in line with other PRRPs, as it defined social security explicitly as a core task of the government (VB 2012: 15).

With regard to the range of social areas covered by welfare provisions, all parties - albeit to different degrees - have emphasised old age and retirement. They defended generous state pensions for people who contributed all their life - which typically excluded immigrants. Health has been another key area for PRRPs, which generally defended a system of state- 
funded healthcare (except for the LN in the 1990s, when it advocated partial privatisation). All parties called for a reduction of user charges. VB, FN and LN, in addition, put family issues at the core of their social policies, promoting active state support for families. VB and FN even proposed a 'maternal salary' for native stay-at-home mothers (FN 2002, 2012; VB 1987a, VB 1991a, VB 2012). In contrast, the PVV never placed great emphasis on the family as a (deserving) core unit in society.

Compared to old age and health care, all parties considered unemployment benefits with much more scepticism. The FN and the LN placed little emphasis on active labour market policies in the first place. The FN insisted on the need for better and more job training programmes only since 1995 (1995b). The PVV shifted from a sceptical position in the mid2000s, when it focused on the need to counter fraud and abuse by those unwilling to work (PVV 2005: 3), to one marked by more generosity ('those who lose their jobs are entitled to welfare', PVV 2012a: 23). From the 1980s onwards, the VB has sternly stressed the duties of the unemployed and the need to control them, arguing that 'only a rigorously respected rights-duties approach can ensure that the available means of our social security go back to those who really need it' (VB 2013: 83).

Overall, our analysis shows that the state has an important role in the welfare mix of the PRR. If we compare our cases across time, we see a similar toning down of the neoliberal agenda in later stages of the parties' life cycles. In the period since the 'Great Recession' in the late 2000s, furthermore, the PRRPs seem to have placed renewed emphasis on the welfare state. However, the generally liberal policies of the 1990s have not given way to outright left-wing welfare policies: the parties have recently called for social justice and conditional welfare based on identity and reciprocity, not an egalitarian idea of universal equality of outcomes. 
PRRPs have supported a recalibration of the welfare state, rather than straightforward retrenchment or expansion.

\section{Redistribution Design}

In terms of redistribution design, the welfare agenda of the PRR primarily emphasises identity as a criterion of deservingness, demanding to preserve and/or prioritize welfare for 'our own kind of people'. Since 'identity' pertains to the fundamental question of who belongs to the community of potential legitimate recipients, it logically precedes the application of the social justice principles of equality, equity, and need, that define the further conditionality of solidarity (see Deutsch 1975: 142; Opotow 1990: 1-4). Nevertheless, PRRP discourses focus also on reciprocity, control and attitude, arguing that only responsible, needy and virtuous citizens who contribute are deserving welfare support.

The identity criterion can be directly related to the concept of welfare chauvinism, which lies at the heart of the PRR welfare ideology and can be defined as identity-based conditional solidarity that restricts social protection to the members of the native community (see: Andersen and Bjørklund 1990: 212; Kitschelt and McGann 1995: 22). Immigrants are typically perceived as a burden on the welfare state.

2 Referring to welfare magnetism (Borjas 1999) and migrants' disproportionate welfare (ab)use (Banting 2010), the PVV and the VB even stressed the incompatibility of immigration and welfare state preservation (PVV 2010a: 5; Spruyt 1995; VB 2013: 21). According to both parties, one key solution for the preservation of the welfare state would be to stop immigration (from Islamic countries), and both introduced the antagonistic choice between 'either a welfare state or an immigration country' (PVV 2012a: 37; Van Grieken 2017a; VB 2018). The welfare chauvinism of all four parties has nevertheless shifted 
between 'welfare exclusion' (the idea that established welfare provisions are categorically ineligible for non-natives); 'welfare favouritism' (giving priority and preferential treatment to the 'natives' in the allocation of social services); and 'welfare conditionality' (eligibility being conditional on minimal period of residence as well as cultural assimilation).

First, all four parties have more or less consistently proposed the total exclusion of migrants from social security for at least a certain period of time. In 1992, for instance, the LN suggested a separate social security system for immigrants, based on their own contributions (LN 1992). Likewise, in 2008, the LN suggested that state pensions should be reserved for Italian citizens, and not be extended to non- EU immigrants (Girardini 2008). The VB has similarly proclaimed that social policies should always be 'limited to our own people with a common cultural identity' (VB 2012: 16; VB 2013: 13). Similar to the LN, the VB has at some points in time proposed 'ethnically-funded welfare systems', resulting in the creation of a separate social security for immigrants, funded by their own contributions (VB 1991b; Dewinter 1991). In France, the concept of 'national preference' has been a hallmark of the FN since the late 1980s. In practice, this alluded to the full exclusion of immigrants from social security schemes, rather than a preference for national citizens (FN 1988a, 2002a, 2007b).

PRRPs sometimes wavered, however, between outright exclusion of immigrants and giving priority to natives. For instance, the 2012 manifesto of the FN marked a radical shift in welfare policies. Within the framework of national preference, the document exhibited a continued focus on the 'French excluded poor'. Yet, in an effort to broaden its exclusive concept of redistribution, 'preference national' was gradually replaced by 'priorité nationale'. This shift was not systematic, yet it showed a marginal loosening of the FN's 
welfare chauvinist conception from the eligibility criterion of 'nativism' to 'nationality', and from preference, which entails exclusion, to priority. At certain occasions, the LN also steered clear of total exclusion of immigrants, asserting that immigrants' access should be made proportional to the capacity of absorption of the Italian labour market, and that the creation of 'new categories of assisted people' (i.e. immigrants) should be avoided (LN 1992; Cassani 2006; Manvulli 2013). More generally, the party argued that employment and social policy disbursements should be available to foreigners only after the needs of Italians were satisfied (Paragone 2006; Girardini 2008).

When PRRPs are willing to open up welfare entitlements to immigrants, it is typically conditional on period of residence, contributions and cultural assimilation. The VB, for instance, asserted to be a supporter of the 'Danish model', whereby rights were only granted to newcomers after seven years of legal residence and at least three years of contribution (VB 2013: 129; VB 2018). Similar provisions of exclusion were proposed in the realm of old-age pensions and healthcare (VB 2013: 130), as well as social housing and assistance (Dewinter 1991; VB 2018). According to the PVV, immigrants should only be eligible for benefits if they had lived and worked in the Netherlands for at least ten years, and mastered the Dutch language (PVV 2010a: 15). In 2012, furthermore, the party proposed to exclude Burquawearing women from welfare, presumably because of their lack of cultural integration (PVV 2012a: 37).

The above examples indicate that the deservingness criterion of identity tends to be applied together with the principle of reciprocity: immigrants are deserving insofar as they have contributed. PRRPs, however, are likely to portray immigrants as 'welfare scroungers'. In the Italian case, for instance, the defence of pensioners is often set against the pretended abuse of 
foreign migrants, who are therefore excluded on both principles: they do not belong to the community of legitimate recipients and they have not contributed to social security (Girardini 2008; Dussin 2008a; LN 2001: 24). The VB, in a similar way, lamented the fact that needy pensioners fell through the social safety net, whilst newly arriving immigrants had easy access to social security and other social rights (VB 2013: 39). Likewise, in a parliamentary debate, PVV leader Wilders proclaimed: 'while elderly people do not get a cent of tax relief, illegal immigrants and asylum seekers are being pampered' (PVV 2015b).

This juxtaposing of immigrants and pensioners shows how the appeal of PRRPs to the criterion of reciprocity per se can best be deduced from their general defence of pensions. The (native) pensioners, as the most deserving category, are often described as citizens who have worked hard all their life, and who should now be rewarded for the fruits of their labour. The PVV, for instance, justified its generous pension policy by characterising pensioners as people who built up the country and should be treated with respect (PVV 2006c). Along similar lines, in 2012 the FN proposed expanded coverage and a lower retirement age for pensioners, warranting such protection on the acknowledgment that they contributed most to the system (in addition to being genuinely in need) (FN 2012b). The LN took a similar position and proposed the reintroduction of an old-age pension for those with 40 years of contributions - which had been scrapped by a previous reform (LN 2018: 5).

Together with the identity and reciprocity criteria, the criteria of control and attitude also play a key role in the PRR's welfare agenda, resulting in the formulation of stricter rules for access to social benefits as well as in a symbolic moralisation of undeserving welfare claimants. The LN, for instance, often accused both Southern Italians and migrants of being unwilling, rather than unable, to work, and of abusing the social security system. From the 
early 2000s onwards, claims about immigrants' supposed abuse of the system became more frequent (LN 2001: 24; LN 2008c). Similarly, the VB has accused both employable Walloons/francophone Belgians and immigrants of deliberately abusing Belgian social security. The party proposes a moralized conditional welfare: Only the 'worthy poor' falling victim to circumstances beyond their control, as well as those who conform to the social expectations in terms of merit and gratitude, should benefit from social support. In this regard, social security is a safety net for those in genuine need, not a social hammock for irresponsible free-riders (Spruyt 1995; 2000; VB 2013).

In the mid-2000s, the PVV also put great emphasis on the criteria of control and attitude. The party argued that citizens' dependence on the welfare state stimulated idleness and inactivity, and proclaimed its willingness to stand up only for the 'genuinely vulnerable': those who were ill or truly unable to work (Wilders, 2005: 5). This has changed more recently with Wilders proclaiming, in 2010, that 'those who lose their jobs are entitled to welfare' (PVV 2012a: 23). The party's attitude towards the long-term unemployed has been somewhat ambiguous, however. The PVV has continued to waver between presenting itself as a party for the underprivileged, on the one hand, and saviour of the hard-working middle-classes, on the other (see e.g. PVV 2012b).

The FN - for long - did not place great emphasis on the criteria of control and attitude: the party has generally defended welfare coverage for French nationals without additional individual conditions. However, in an extensive 2012 welfare programme, Marine Le Pen introduced strict measures to target welfare scroungers. For instance, the FN proposed to introduce a biometric social security pass in order to scrutinise and sanction beneficiaries more efficiently; and to exclude "cheaters" and usurpers from welfare rights (FN 2012b). 
Finally, an important element of any redistributive design relates to the question of who bears the burden. PRR positions on taxation tend to follow a liberal approach of low businessfriendly rates. The LN has consistently defended a reduction in both income and corporate tax, and recently demanded the introduction of a flat income rate at around $15 \%$ of yearly family income (LN 1996; La Padania 2008b; LN 2018: 3). Although the VB rejected - after a conflict between the solidarist and neoliberal factions inside the party - the flat income tax already in 1996 (Spruyt 2000: 166-171), it also consistently called for the reduction of taxation. A similar position has been defended by the PVV, which has consistently called for tax cuts (Wilders 2005; VB 2013: 79-81). The FN has traditionally also supported lower taxation - up to 1995 Jean-Marie Le Pen argued for a reduction of income tax. In its 2012 manifesto, however, the FN defended higher income tax for the richest households, and a new rate of VAT for 'luxury products'.

Given the support for, sometimes even generous, welfare policies recently shown by PRR parties, liberal supply-side measures might suggest a degree of inconsistency. To overcome this, all mentioned parties have often referred to the savings they would obtain from the exclusion of foreigners from social security, as well as more efficient governance. In the case of the VB and LN, ending inter-territorial transfers to, respectively, Wallonia and Southern Italy has also been part of the solution. The PVV, for its part, has proposed to stop spending money on expensive 'left-wing hobbies' like the environment, development aid, and art subsidies (e.g. PVV 2012; 2016). The party also - and to an increasing extent - portrayed the European Union as a wasteful and money-consuming project, and stressed the financial benefits of leaving the bloc. Along these lines, PRRPs can align their seemingly contradictory redistributive welfare agenda - entailing more welfare generosity for their own people - with 
their neoliberal regulatory economic policies focusing on lower taxation.

\section{Implementation Process and Outcomes}

PRRPs are ambivalent about welfare redistribution as they support welfare state recalibration instead of retrenchment. They nevertheless articulate a fundamental critique of the welfare state as an institution. As a rule of thumb, PRRPs are very sceptical about the management of welfare arrangements by the state in terms of efficiency (i.e. cost-effectiveness) and effectiveness (i.e. legitimate redistribution). All PRRPs openly question the ability of the current welfare state to reduce poverty and to guarantee welfare for those in 'real need'. Both the LN and the VB, for instance, have complained that immigrants often unjustifiably and disproportionally receive welfare benefits, that welfare system abuse is rife, and that service delivery is not cost-effective (LN 1992, 2001: 24, 2008c; VB 2013: 41, 62, 102). The PVV has identified multiple welfare state deficiencies as well, including fraud and welfare abuse, the dismal situation in care homes, waiting lists for hospitals, and the disproportional amount of (Muslim) immigrants on benefits. From the 1980s, the FN has similarly denounced the 'mismanagement' of the welfare state (FN 1988a).

One other recurring element of PRRPs' welfare criticism is the claim that the welfare state has unintended economic and moral consequences (Van Oorschot 2010). The VB, for instance, has consistently warned against the increased burden of taxation, which weakens the competitiveness of firms, as well as the development of a dependency culture resulting in an immoral 'class of profiteers' with no intention to contribute to the system (VB 2013: 12 and 71-84). The LN and the PVV similarly argued against overly extensive welfare arrangements in their more economically liberal periods (respectively, in the 1990's and mid2000s). The PVV declared that 'the extensive welfare state [led to] the destruction of our 
cultural and moral capital' (PVV 2006a) and that welfare state regulations hampered a healthy business climate (PVV 2006b), while also blaming the government for the fact that '[m]illions of people sit at home on benefits' (PVV 2006c). Yet, as discussed previously, in later years the party described the welfare state in a more favourable light. The LN argued that extensive social support would naturally generate welfare-dependency (LN 1992; Stefani 1996), but, since the late 1990s, the party has focused more on accusations of inefficiency and abuse by specific categories of recipients (mostly by Southerners and immigrants) rather than on the unintended consequences of welfare (LN 2001: 24; Baiocchi 2008; Neri 2013). In contrast, and perhaps due to intra-party disagreements, the FN did not engage directly with the unintended consequences of the welfare state in its official party documents, except for arguing that welfare benefits constituted a strong incentive for migrants to come to France (FN 2012b).

Who, according to the parties, is to blame for the shortcomings of the welfare state? In their PRR blame-attribution framework the usual suspects are the immoral undeserving welfare scroungers (not least immigrants) and the political elites, who are accused of failing to act against abuse and overuse. Immigrants and other welfare scroungers have typically been blamed for cheating the system. This was evident in the discourse of the FN, which considered immigration as the cause of high unemployment and financial burden for the welfare state (FN 1988a, 1995a, 2012b). While the LN similarly portrayed immigrants as undeserving, it sometimes portrayed them (and Southerners) as victims of the clientelistic strategies of the Left, which was accused of making them dependent on welfare for electoral purposes (LN 1994: 19-24; 2001: 3-4 and 24; LN 2013b). The bureaucracy and the state have also been directly attacked for their hypertrophic, inefficient and unaccountable nature. ${ }^{3}$ 
Criticism of political opponents and the state was also central to other PRRPs' blame attribution. The PVV repeatedly blamed the government of the day, and the Dutch political elites more generally, for making wrong choices or not having their priorities straight: money was spent on the EU (not least to prop up corrupt Greece), asylum seekers and other supposedly senseless causes, whilst deserving natives were left in the cold (e.g. PVV 2016). Similarly, the VB has criticised Wallonia and the francophone political class, notably the Socialist Party, which supposedly exploited the hard work of the Flemish people, as well as the trade unions, which have been deemed responsible for 'Belgian immobilism' and accused of failing to recognise that workers and employers have more shared than conflicting interests (VB 2013: 29-30). In general, the hostility towards organized interests is rooted in a widespread populist critique of neo-corporatism. The FN has consistently blamed incumbent parties for the alleged inefficient management of welfare programmes, insisting on the shared responsibility of the right and the left, which were assumed to have conducted the same policies (FN 1995c; 2012a). The FN's blame attribution to mainstream political parties of welfare state mismanagement has generally been framed in terms of a radical and urgent mission: irrespective of its (in)efficiency, the welfare state's actual survival is at stake (FN 2007a).

5.

Discussion and Conclusion: the PRR's Welfare Agenda between

\section{Welfare Chauvinism, Producerism and Populism}

The cases under consideration in this study show some variation with regard to specific welfare policies; yet there are sufficient commonalties to suggest the existence of a typical PRR welfare agenda, which integrates chauvinist and producerist frames into a welfare populist discourse (see also Abts and Kochuyt 2014). Our analysis shows that the PRR 
welfare agenda describes the redistribution afforded by welfare arrangements as highly conditional and strongly dependent on deservingness criteria not only related to identity, but also reciprocity, control and attitude. Furthermore, it becomes clear that PRRPs' positions not only refer to the welfare contract established among contributors and recipients within the social body, but also to the social contract between citizens and the state. Their ideas thus pertain both to the identification of legitimate (and illegitimate) recipients of social support, as well as to the efficient and effective delivery of social benefits and services.

When dealing with the welfare state, the central claim of PRRPs is not minimal social redistribution or the dismantling of the welfare state, but rather a recalibration where the access to and the design of welfare benefits and services is not universal and egalitarian, but highly selective and conditional on identity, reciprocity, control and attitude. Moving away from both a universal leftist and neoliberal rightist framing of the welfare state, this welfare conditionality and selective generosity is articulated around the three ideological core elements of PRRPs: nativism, authoritarianism and populism. Although this is in line with other analyses (e.g. Afonso and Papadopoulos 2015; Ennser-Jedenastik 2016), we argue that the PRR's welfare logic needs to be more precisely related to all deservingness criteria, and that the multidimensionality of the welfare state needs to be taken into account.

The first frame used by the PRR is welfare chauvinism. Previous authors have described this concept as a type of 'exclusive solidarity', limited only to the 'natives'. Integrating the criteria of deservingness into our typology, we define welfare chauvinism as a conditional conception of solidarity advocating social closure primarily based on the criterion of identity (Abts and Kochuyt 2013, 2014). Welfare chauvinism sometimes implies an unconditional exclusion of immigrants (as for the FN in the 1980s), but more often it assumes a temporal 
ban until some residence, contributory or cultural integration requirements are fulfilled, as recently argued by the PVV and the VB. In other cases, PRRPs proposed granting priority to natives (think of the VB's slogan eigen volk eerst and the FN's préférence nationale), or conceived of separate social security funds for natives and foreigners (as proposed by the LN and the VB). In all cases, however, especially in conditions of economic austerity, these 'softer formulations' of chauvinism de facto imply a substantial limitation, if not the outright exclusion of immigrants. A related question concerns the precise identity of the deserving community. It is sometimes ambiguous whether these parties refer to citizenship, ethnicity, or something else as the identity criterion for accessing social benefits and services. Although it is rarely spelled out openly, PRRPs mostly seek to exclude non-EU immigrants irrespective of occasional references to, for instance, 'welfare tourism' within the EU (VB, PVV, LN). Sharing a regionalist agenda, the VB and LN have also resorted to the criterion of identity to exclude fellow citizens speaking a different language or inhabiting particular regions.

Although identity is a crucial PRR criterion of deservingness, other criteria play an important role as well, notably: control, attitude and reciprocity. These criteria refer to moral principles of equity and fairness, and relate to a judgement about the behaviour of welfare recipients. On the one hand, they build on a principle of equity, whereby people who contributed more to the system should be advantaged when in need. This is clear when looking at pensions. Our four parties have all defended the rights of pensioners (who arguably contributed their entire life to the welfare system), pitting them against those of newcomers (who did not add enough to the public purse). In this perspective, giving immediate welfare access to immigrants is an injustice towards the established elderly. On the other hand, considering a wider range of deservingness criteria than just identity allows to perceive the authoritarian 
nature of the PRR's ideology: the parties discriminate between morally deserving and underserving recipients, and emphasise the need to punish abusers. Both the $\mathrm{LN}$ and the VB have referred to immigrants and Southern Italians/Walloons on benefit as abusers of the welfare system because they are unwilling to work, rather than truly needy. The PVV has recently softened its, previously very critical, stance towards the unemployed, but it has remained ambiguous on this matter, while in 2012 the FN proposed a sweeping range of measures to detect and punish welfare 'scroungers'.

Building on Abts and Kochuyt (2013, 2014), we describe the articulation of these principles by the PRR as welfare producerism; that is, a conditional conception of solidarity based on the deservingness criteria of control, attitude and reciprocity. PRRPs typically argue that some recipients fail to contribute their share, deliberately abuse the system despite being responsible for their situation of need, and fail to try hard enough to escape this situation. Within this framework, all citizens can conditionally take advantage of the welfare state, if they work and contribute. This position promotes a moralisation of social citizenship, since people should earn their share of welfare provisions by being 'active, responsible, productive and grateful citizens' (Schinkel 2010; see also Bowles and Gintis 2000). Consequently, the PRRPs' inclusion/exclusion code of the welfare state is not based on identity only, but also on productivity and morality, illustrating a significant shift from a formal to a moral notion of membership.

Producerism and chauvinism can, and should, be distinguished analytically, since they refer to different underlying criteria. However, both concepts are often mixed in reality through a 'culturalisation of morality', whereby immoral (ethnic) outsiders are portrayed as 'naturally' inclined to cheat the system (Abts and Kochuyt 2017; Kochuyt and Abts 2017). Typically, 
immigrants are portrayed as 'welfare tourists' or 'fortune seekers' who are attracted by generous social policies and willingly live on benefits. The use of the criteria of control, attitude and reciprocity are not a property of the PRR only, as they are often inherent in many programmes of active labour market policies throughout Europe. The PRR stands out in its authoritarian emphasis on civic duties and the need to punish abuse. Other parties, such as Christian- or social-democrats, tend to justify similar policies by referring to their emancipatory nature (see Dingeldey 2007; Eichhorst et al. 2008).

Our analysis also suggests that the two complementary frames of welfare chauvinism and producerism are held together, in PRR discourse, by welfare populism. This third frame does not, strictly speaking, refer to 'conditional solidarity' but rather to the social contract between the citizens and the state. The parties in our study clearly denounce the concrete malfunctioning of the welfare state, and they accuse the neo-corporatist ${ }^{4}$ elite of failing to use the community's resources for the people. The welfare state-as-institution is not only criticised for being inefficient, but also for prioritising the wrong types of recipients (not least immigrants), sometimes for political elites' own (electoral) gain - both the LN and the VB have made similar accusations against the Left, while the PVV and the FN have tended to blame both Left and Right for taking the (same) wrong choices. Elites are criticised for defending a welfare state that fails to serve the interest of the deserving common man, and PRRPs thus construct a vertical antagonism between 'the establishment' and 'the people', which is constitutive of their welfare-populist thinking. PRRPs formulate an apparently 'egalitarian' (but in fact selective) critique of the welfare state by blaming the establishment including both parties and organised interests such as trade unions - for the alleged fact that welfare arrangements fail to adequately protect the real deserving poor, i.e. the (native) common people in genuine need. Instead, the welfare state is argued to pamper a self- 
interested and privileged class of civil servants whose actions support the freeriding 'welfare scroungers' (Derks 2006; De Koster et al. 2013; Abts and Kochuyt 2014). In this sense, PRRPs are not only restricting, or prioritising, welfare access to 'our own people', but also criticising 'the way welfare is arranged and delivered in a matter that neglects the interests of the common man' (Ketola and Nordensvard 2018: 179).

[Figure 1 about here]

In the discursive triangle formed by these three frames, the nativist logic (welfare chauvinism) and the authoritarian logic (welfare producerism) do not only target undeserving migrants and welfare scroungers, but also the welfare state as a (neo-corporatist) political institution (welfare populism). Although the ideological underpinnings of chauvinism and producerism are very different, both refer to selective solidarity and can unite within the master-frame of welfare populism. The combination of both frames allows for defending welfare arrangements in principle, and even to argue in favour of their expansion in some areas like old age care and pensions, while, at the same time, criticising the concrete functioning of the welfare state. As shown for the electorate of the VB (Abts and Kochuyt 2013), thanks to the combination of these three frames, PRRPs can attract discontented voters from the 'left' and 'right' alike, and move beyond the traditional socio-economic left-right cleavage.

What are the implications of this conceptualisation of the PRR's welfare agenda? Although PRRPs' positions on the welfare state might seem ambiguous (if not contradictory at times), they incarnate a consistent, although flexible, framework. Even if these parties stress and combine the chauvinist, producerist or populist aspects in their welfare discourse in different 
ways, they all tend to articulate a welfare discourse on selective social redistribution that privileges the deservingness criteria of identity, control and reciprocity, as well as the opposition between the people and the elite. Hence, the PRR welfare agenda goes beyond welfare chauvinism. Although identity does remain the cornerstone of PRRPs' social policy proposals, it is fundamentally complemented by moral judgments about welfare recipients' behaviour, as well as by a populist criticism of the welfare state. Furthermore - and this is arguably one of the most important contributions of our paper - we show that PRRPs have engaged with the welfare state as a multi-dimensional institution, touching upon each of the three dimensions in which it can be analytically divided: agency and scope; deservingness; implementation and outcome.

At the same time, our analysis and conceptualisation also leave some questions unanswered. How do different welfare systems moderate the emphasis of specific parties on particular policy areas and deservingness criteria? Is the multi-dimensional approach also applicable to the realm of regulative economic policies? And, if so, what is the relationship between these policies and the PRR's welfare agenda? Although, for reasons of scope, we have not addressed these questions in this paper, we strongly believe that our analytical framework and ensuing conceptualisation of the PRR's welfare agenda can help contribute to answering these issues. 


\section{Bibliography}

\section{Primary sources}

See supplemental material.

\section{$\underline{\text { Secondary sources }}$}

Abts, K. and Kochuyt, T. (2013) De vreemde bedreiging van de verzorgingsstaat. Tijdschrift voor Sociologie 34(3-4), 227-249.

Abts, K. and Kochuyt, T. (2014) Radical Right Voters and Welfare State. Between Welfare Chauvinism, Producerism and Welfare Populism, Paper presented at the 'Welfare State and Radical Right' workshop, European University Institute, Florence, May 20-21.

Abts, K. and Kochuyt, T. (2017) De gepaste plaats van de vreemdeling: radicaalrechtse kiezers over integratie. Sociologos 38(1-2), 78-97.

Afonso, A. (2015) Choosing whom to betray: populist right-wing parties, welfare state reforms and the trade-off between office and votes. European Political Science Review 7, 271-292.

Afonso, A. and Rennwald, L. (2018). 'Social Class and the Changing Welfare State Agenda of Radical Right Parties in Europe'. In P. Manow, B. Palier and H. Schwander (eds.), Welfare Democracies and Party Politics. Oxford University Press.

Andersen J. and Bjørklund T. (1990) Structural Changes and New Cleavages: The Progress Parties in Denmark and Norway, Acta Sociologica 33(2), 195-217.

Arts, W. and Gelissen, J. (2002) Three worlds of welfare capitalism or more? A state- of-theart report. Journal of European Social Policy 12(2), 137-158.

Banting, K.G. (2010) Is There a Progressive's Dilemma in Canada? Immigration, Multiculturalism and the Welfare State, Canadian Journal of Political Science 43(4), 797 820.

Betz, H.-G. (1994) Radical Right-Wing Populism in Western Europe. New York: St. Martin's Press.

Blaikie, N (2000) Designing social research. Cambridge: Polity Press. 
Bommes, M. (2012) 'National Welfare State, Biography and Migration: Labour Migrants, Ethnic Germans and the Re-Ascription of Welfare State Memebrship'. In C. Boswell and G. D'Amato (eds.) Immigration and Social Systems. Collected Essays of Michael Bommes, Amsterdam: Amsterdam University Press, pp. 37-58.

Borjas, G. J. (1999) Immigration and Welfare Magnets. Journal of labor economics 17(4), $607-637$.

Brubaker, R. (1989) 'Membership without Citizenship: The Economic and Social Rights of Noncitizens'. In R. Brubaker (ed.) Immigration and the Politics of Citizenship in Europe and North America, Lanham: University Press of America.

Careja, R., Elmelund-Præstekær, C., Klitgaard, M.B. and Larsen, E.G. (2016) Direct and Indirect Welfare Chauvinism as Party Strategies: An Analysis of the Danish People's Party. Scandinavian Political Studies 39, 435-457.

Cook, F. (1979) Who should be helped: Public support for social services. Beverly Hills, CA: Sage.

Coughlin, R.M. (1980) Ideology, Public Opinion and Welfare Policy: Attitudes Towards Taxes and Spending in Industrial Societies. Institute of International Studies, Research Series n. 42 .

De Koster, W., Achterberg, P., and Van der Waal, J. (2013) The new right and the welfare state: The electoral relevance of welfare chauvinism and welfare populism in the Netherlands, International Political Science Review 34(1), 3- 20.

De Lange, S. (2007) A New Winning Formula? The Programmatic Appeal of the Radical Right, Party Politics 13(4), 411-435.

Derks, A. (2006) Populism and the Ambivalence of Egalitarianism: How do the Underprivileged Reconcile a Right Wing Party Preference with their Socioeconomic Attitudes?. World Political Science Review 2(3), 175-200.

De Swaan, A. (1988). In care of the state. Amsterdam: Bakker.

Deutsch, M. (1975). Equity, equality, and need: What determines which value will be used as the basis of distributive justice?. Journal of Social issues 31(3), 137- 149.

Dingeldey, I. (2007) Between workfare and enablement - The different paths to transformation of the welfare state: A comparative analysis of activating labour market policies. European Journal of Political Research 46(6), 823-851.

Eichhorst, W., Kaufmann, O., Konle-Seidl, R. and Reinhard, H.-J. (2008) 'Bringing the Jobless into Work? An Introduction to Activation Policies'. In W. Eichhorst, O. Kaufmann 
and R. Konle-Seidl (eds.) Bringing the Jobless into Work? Experiences with Activation Schemes in Europe and the US. Berlin: Springer, pp. 1-16.

Ennser-Jedenastik, L. (2016) A Welfare State for Whom? A Group-based Account of the Austrian Freedom Party's Social Policy Profile. Swiss Political Science Review 22(3), 409427.

Ennser-Jedenastik, L. (2018) Welfare Chauvinism in Populist Radical Right Platforms: The Role of Redistributive Justice Principles. Social Policy \& Administration 52(1), 293-314.

Esping-Andersen, G. (1990) The Three Worlds of Welfare Capitalism. Cambridge: Polity Press.

Esping-Andersen, G. (2004) 'After the Gloden Age? Welfare State Dilemmas in a Global Economy'. In G. Esping-Andersen (ed.), Welfare States in Transition: national adaptations in global economies. London: Sage, pp. 1-31.

Feagin, J. (1972) Poverty we still believe that God helps who help themselves, Psychology Today 6, 101-129.

Feather, N. (1974) Explanation of poverty in Australian and American samples: The person, society and fate. Australian Journal of Psychology 26, 199-216.

Fenger, M., (2018) The social policy agendas of populist radical right parties in comparative perspective. Journal of International and Comparative Social Policy 34(3), 188-209.

Ferrera, M. (2005) The Boundaries of Welfare. Oxford: Oxford University Press.

Freeman, G.P. (1986) Migration and the Political Economy of the Welfare State. The Annals of the American Academy of Political and Social Sciences 485, 51-63.

Hainsworth, P. (ed.) (2000) The Politics of the Extreme Right: From the Margins to the Mainstream. London: Pinter.

Häusermann, S. (2010) The Politics of Welfare State Reform in Continental Europe: Modernization in Hard Times. Cambridge: Cambridge University Press.

Ivaldi, G. (2015) Towards the median economic crisis voter? The new leftist economic agenda of the Front National in France. French Politics 13(4), 346- 369.

Ivarsflaten, E. (2008) What Unites the Populist Right in Western Europe? Reexamining Grievance Mobilization Models in Seven Successful Cases. Comparative Political Studies 41(1), 3-23.

Keskinen, S., Norocel, O.C. and Jørgensen, M.B. (2016) The politics and policies of welfare 
chauvinism under the economic crisis, Critical Social Policy 36, 321-329.

Kitschelt, H. (2007) Growth and Persistence of the Radical Right in Postindustrial Democracies: Advances and Challenges in Comparative Research. West European Politics 30(5), 1176-1206.

Kitschelt, H. and McGann, A. (1995) The Radical Right in Western Europe. Ann Arbor: University of Michigan Press.

Kochuyt, T. and Abts, K. (2017) Ongehoord populisme. Vlaams Belang kiezers over stad, migranten, welvaartsstaat, integratie en politiek. Brussel: ASP editions.

Lefkofridi, Z. and Michel, E. (2017) 'The electoral politics of solidarity: The welfare agendas of radical right'. In K. Banting and W. Kimlycka (eds.). The Strains of Commitment: the Political Sources of Solidarity in Diverse Societies. Oxford: Oxford University Press.

Mau, S. (2003) The Moral Economy of Welfare. London: Routledge.

McGann, A. and Kitschelt, H. (2005) The Radical Right in the Alps: the Evolution of Support for the Swiss SVP and Austrian FPÖ, Party Politics 11(2), 147-171.

Mudde, C. (2000) The Ideology of the Extreme Right. Manchester: Manchester University Press.

Mudde, C. (2007). Populist Radical Right Parties in Europe. Cambridge: Cambridge University Press.

Oesch, D. (2008) Explaining Workers' Support for Right-Wing Populist Parties in Western Europe: Evidence from Austria, Belgium, France, Norway and Switzerland. International Political Science Review 29(3), 349-373.

Ong, BK. (2012) Grounded Theory Method (GTM) and the Abductive Research Strategy (ARS): A Critical Analysis of their Differences'. International Journal of Social Research Methodology 15(5), 417-432.

Opotow, S. (1990) Moral exclusion and injustice: An introduction. Journal of social issues, 46(1), 1-20.

Otjes, S., Ivaldi, G., Jupskås, A. R., \& Mazzoleni, O. (2018) It's not Economic Interventionism, Stupid! Reassessing the Political Economy of Radical Right-wing Populist Parties, Swiss Political Science Review 24(3), 270-290.

Roosma, F., Gelissen, J., and van Oorschot, W. (2013) The Multidimensionality of Welfare State Attitudes: A European Cross-National Study. Social Indicators Research 113(1), 235255. 
Röth, L., Afonso, A. and Spies, D.C., (2018) The impact of Populist Radical Right Parties on socio-economic policies. European Political Science Review 10, 325-350.

Rovny, J. (2013) 'Where do radical right parties stand? Position blurring in multidimensional competition'. European Political Science Review 5(1), 1- 26.

Spruyt, M. (1995) Grove borstels. Leuven: Van Halewijck.

Spruyt, M. (2000) Wat het Vlaams Blok verzwijgt. Leuven: Van Halewijck.

Van Oorschot, W. (2000) 'Who should get what, and why?', Policy and Politics 28(1), 3349.

Van Oorschot, W. (2006) 'Making the difference in social Europe: deservingness perceptions among citizens of European welfare states', Journal of European Social Policy 16(1), 23-42.

Van Oorschot, W., Roosma, F., Meuleman, B. and Reeskens, T. (2017) The social legitimacy of targeted welfare: Attitudes on welfare deservingness. Cheltenham: Edward Elgar.

Will, J. (1993) The dimensions of poverty: Public perceptions of the deserving poor, Social Science Research 22, 312-332. 
Table 1 - The multi-dimensionality of welfare

\begin{tabular}{|c|c|c|}
\hline Dimension & Issue & Sub-dimensions \\
\hline Agency and scope & $\begin{array}{c}\text { Who should take care of welfare and } \\
\text { how much? }\end{array}$ & $\begin{array}{c}\text { Welfare mix } \\
\text { Range } \\
\text { Degree }\end{array}$ \\
\hline $\begin{array}{c}\text { Redistribution design } \\
\text { Implementation and } \\
\text { outcomes }\end{array}$ & $\begin{array}{c}\text { Are welfare arrangements delivered } \\
\text { efficiently and effectively? Do they } \\
\text { reach their goal? }\end{array}$ & $\begin{array}{c}\text { Defficiency and } \\
\text { effectiveness } \\
\text { (Un)intended } \\
\text { Outcomes }\end{array}$ \\
\hline
\end{tabular}




\footnotetext{
${ }^{1}$ The Netherlands was initially placed by Esping-Andersen in the social-democratic group. Later authors have considered it as belonging to the continental category, but some have also labelled it as liberal. Esping-Andersen himself referred to it as the 'Dutch enigma' (see Arts and Gelissen 2002).

${ }^{2}$ The LN and the VB are more complex cases because the identity criterion has not only referred to foreign migrants, but also to inhabitants of other regions of the parent state. For instance, frustration with the so-called 'North-South transfers' and the 'over-solidarity' with Wallonia, resulted in the VB's call to split the Belgian social security system between an independent Walloon and Flemish welfare state (VB, 1990; VB, 2012; 2013). However, the denial of solidarity with Southern Italy or Wallonia has rarely been based only on the criterion of identity, which has played a much more important role with regard to foreign, especially non-EU, migrants.

${ }^{3}$ In more recent years, Europe and big banks have also been identified by the party as actors responsible for the economic hardship experienced by the people.

${ }^{4}$ Neo-corporatism refers to the socio-economic elite of labour-union and business representatives.
} 